\title{
ISOLATION AND PRESENCE OF ANTIMALARIAL ACTIVITIES OF MARINE SPONGE Xestospongia sp.
}

\author{
Murtihapsari $^{1, *}$, Apriani Sulu Parubak ${ }^{1}$, Bertha Mangallo ${ }^{1}$, \\ Wiwied Ekasari ${ }^{2}$, Puji Budi Asih ${ }^{3}$, and Ayu Indah Lestari ${ }^{1}$ \\ ${ }^{1}$ Department of Chemistry, Faculty of Mathematics and Natural Sciences, Papua State University, \\ JI. Gunung Salju Kampus Amban Manokwari, West Papua 98314, Indonesia \\ ${ }^{2}$ Faculty of Pharmacy, Airlangga University, Kampus B Unair, \\ JI. Dharmawangsa Dalam Surabaya East Java 60286, Indonesia \\ ${ }^{3}$ Eijkman Institute for Molecular Biology, Jl. Diponegoro 69, Jakarta Indonesia
}

Received April 27, 2013; Accepted August 28, 2013

\begin{abstract}
Plasmodium falciparum, the agent of malignant malaria, is one of mankind's most severe scourges, mainly in the tropic world. Efforts to develop preventive vaccines or remedial drugs are handicapped by the parasite's rapid evolution of drug resistance. Here, we presented an advance work on examination of antimalarial component from marine life of Xestospongia sp., the study is based on hexane extraction method. The premier result, we obtained five fractions. Among these five fractions, the fourth has the most potent inhibitory against the growth of P. falciparum 3D7 with an $I C_{50}: 7.13 \mu \mathrm{g} / \mathrm{mL}$. A compiled spectrum analysis, FTIR, ${ }^{1} \mathrm{H}-\mathrm{NMR}$ and GC-MS, revealed that the fourth fraction consisted abundantly of two secondary metabolites such as flavonoids and triterpenoids. Finally, our results suggest a plausible structure rooted to the base of ibuprofen.
\end{abstract}

Keywords: sponge; xestospongia; papua; antimalarial

\section{ABSTRAK}

Plasmodium falciparum adalah parasit penyebab utama penyakit malaria, yang merupakan salah satu penyakit terparah di negara-negara tropis. Sayangnya, upaya pengembangan vaksin preventif atau obat remedial lainnya sedang menghadapi kendala besar karena cepatnya evolusi resistensi obat malaria. Berikut, kami ketengahkan hasil riset kali ini tentang uji aktivitas antimalaria dari spons laut Xestospongia sp. yang diekstraksi dengan menggunakan pelarut n-heksana. Hasil pengamatan menghasilkan lima fraksi. Hasil identifikasi menggunakan FTIR, ${ }^{1} \mathrm{H}-\mathrm{NMR}$ dan GC-MS, menunjukkan bahwa fraksi keempat menghasilkan daya hambat tertinggi terhadap pertumbuhan P. falciparum 3D7 (IC $\left.C_{50}: 7,13 \mu \mathrm{g} / \mathrm{mL}\right)$. Dapat kami laporkan pula bahwa fraksi keempat terdeteksi mengandung senyawa metabolit sekunder, flavonoid dan triterpenoid. Terakhir, penelitian ini menghasilkan suatu struktur dugaan dengan basal ibuprofen.

Kata Kunci: spons; xestospongia; papua; antimalaria

\section{INTRODUCTION}

Malaria is the most world severe and infectious disease infected 2.4 billion people, across over 100 countries [1-3]. Global cases are reported to about 515 million a year [4-5]. This disease also is responsible of the human deaths about 1.5-3.0 million people per year [6-5], most of the death cases occurred in Africa and the other tropical world [7-8].

A compiled recent investigation have stipulated that Indonesia is home of 20 vectors of malaria associating with four species known of Plasmodium [9]. Cases of malaria in Indonesia are estimated to about 89 millions cases by 2011 , one people died per a hundred of

* Corresponding author. Tel/Fax : +62-8124863848

Email address: murtihapsari@pnsmail.go.id thousand cases [5]. This infectious disease has spread across the archipelago including Sumatera, Borneo, Java, Sulawesi, Maluku and Indonesian New Guinea Island. In the eastern most province of archipelago, Papua and West Papua are well known to have an important case of malaria [10]. Current report revealed that malaria is being infected seventy people per a hundred populations; most of them are women and children [5].

In West Papua particularly, searching for a credible drug for antimalarial treatment is scarce. In addition, the most commonly drugs such as chloroquine, primaquine and sulfadoxinepyrimethamine already reported to be resistance to

Murtihapsari et al. 
$P$. falciparum and $P$. vivax [9,11-12], elevating the complexity of the malaria treatments [13-14]. Related to this meticulous fact, the chloroquine is now listed to be unrecommended drug by WHO [15-16] since its important toxicities to the woman pregnancies [17-18].

It's generally admitted that the most antimalarial drugs used were extracted from plant herbs and some of their derive medicaments are reportedly resistance to malaria [19-21]. In respond to the drugs already resistance, many researchers have focus to explore a wide range of the habitats including all spectrum of fresh, brackish and salt water [22]. In recent decades, marine sponge (e.g Xestospongia, Haliclona) are largely used as the potential source of the new drugs, a dozen patenting already obtained from this unique biota, many others researchers are continuing to discover of new compound from other taxa [23-24]. In this context, Indonesia harbors more than 800 species of marine sponge [25-26], in other words this country represents more than $70 \%$ of the total marine sponge species in the globe [27-28].

As a part of the global encourage in finding solution for malaria, we are characterizing the potential components of the marine sponge for antimalarial agents. In the present work, we are initially commenced an examination of antimalarial activities based on Papuan sponge of Xestospongia sp., a taxon of marine life that has widely distribution in the country.

\section{EXPERIMENTAL SECTION}

\section{Materials}

The study was based on specimen of marine sponge Xestospongia sp., collected in Yapen Island, Papua, Indonesia (1 53'56'S-136 13'14'E). The following chemicals were used including ethyl acetate (p.a), hexane (p.a), gel silica, TLC plat, Liebermann-Burchard, Dragendorff, Bouchard and Mayer, potassium hydroxide, $P$. falciparum strain 3D7 developed by the Eijkman Institute for Molecular Biology and Airlangga University, Roswell Park Memorial Institute (RPMI) 1640 containing the L-glutamine, $\mathrm{N}$-(2-Hydroxyethyl) piperazineethanesulfonate acid (HEPES), $\mathrm{NaHCO}_{3} 5 \%$, antibiotic gentamicin sulfate injection, $\mathrm{NaCl} 0.9 \%$ and $3.5 \%$, sorbitol $5 \%$, serum, RBC "O", the anticoagulant Citrate Phosphate Dextrose (CPD), aqua-bides, giemsa, buffer phosphate $\mathrm{pH} 7.2$, alcohol $70 \%$ and Bunsen burner.

\section{Instrumentation}

The spectrums were performed by using the following instruments: the Fourier Transform Infrared Spectroscopy (FTIR)-Shimadzu Prestige-21; ${ }^{1} \mathrm{H}-\mathrm{NMR}$. The ${ }^{13}$ C-NMR spectrums were obtained on JEOL JNM
ECA at $500 \mathrm{MHz}$; MS spectrums were recorded on GC-MS (Agilent MS_5971).

\section{Procedure}

The obtained specimens of marine sponge were collected by scuba in about $10 \mathrm{~m}$ depth. Six kilograms of sponge were extracted following maceration method by using about twelve liter of hexane. Removing the solvents from samples have been performed through the evaporation method that were used rotary evaporator, afterwards the extracts have been stored at the freezer.

The fractionation method following a previous work [29] with some modification, in the current work, fractionation was carried out in vials by using a combination hexane and ethyl acetate (3:1). The purification was performed by column chromatography. Obtained eluates were separated and identified with Thin Layer Chromatography (TLC) at the wave lengths between 254 and $366 \mathrm{~nm}$.

The culture of $P$. falciparum 3D7 strain (a chloroquine-sensitive clone) was used in the experiment, were maintained by in vitro techniques adapted by Trager and Jensen (1976) in human red blood cells (blood type O+) with $5 \%$ hematocrit in RPMI 1640 (GIBCO BRL, USA) supplemented with $22.3 \mathrm{mM}$ HEPES (Sigma), Hypoxanthine and Sodium bicarbonate) plus $10 \%$ human $\mathrm{O}+$ plasma.

Test were performed in duplicate of 24-well culture plates with an initial and experimental parasitemia of $1 \%(1 \mathrm{~mL}$ suspension each well). Sample was prepared at various concentrations for analysis. Test culture was then incubated in a multigas incubator at $37^{\circ} \mathrm{C}$ for $48 \mathrm{~h}$. After incubation, thin blood films were made on glass slide, air dried are fixed in methanol and stained with Giemsa. Fifty percent inhibitory concentration $\left(\mathrm{IC}_{50}\right)$ was estimated with the approach of Probit Analysis.

The secondary metabolites such as the flavonoids and steroids/triterpenoids, were identified using the phytochemistry method, those method is derived and adapted from classical phytochemistry protocol [30].

Structure of molecule was reconstructed using the ChemDraw Ultra 10.0 [31]. The structure was identified using the Dictionary of Natural Products [32-33] and then performed by ChemDrawUltra 10.0 [31].

\section{RESULT AND DISCUSSION}

A total of $15.8 \mathrm{~g}$ of extraction was obtained, using hexane solvent, has produced a rendement of $0.003 \%$. Comparing to the same solvent were used on other works, the authors obtained a total rendement about $0.96 \%$. Lowly rendement yielded in the present study is 

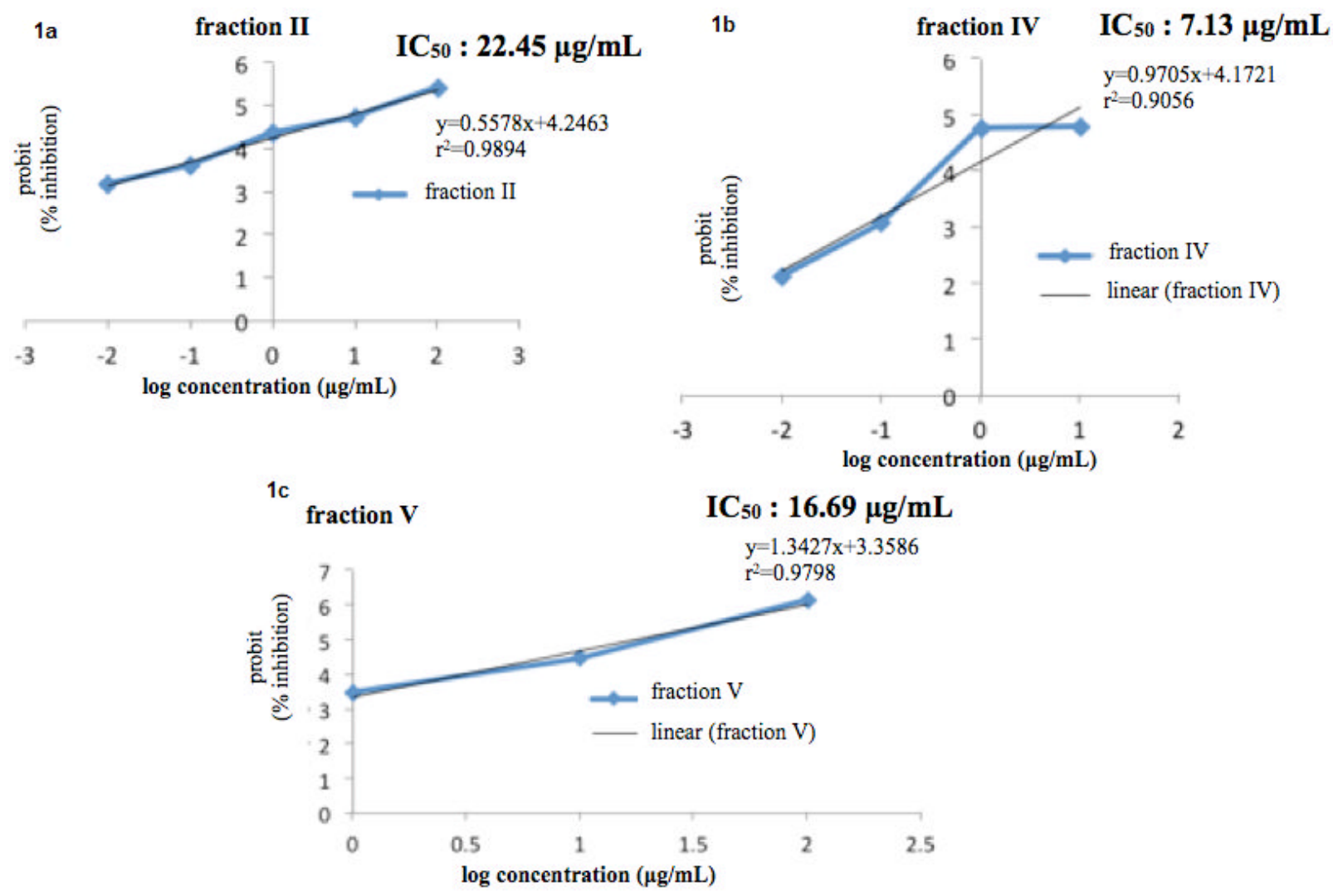

Fig 1. Percentage inhibition of the three fractions against Plasmodium falciparum, fraction II: IC50 $22.45 \mu \mathrm{g} / \mathrm{mL}$; IV: IC50 $7.13 \mu \mathrm{g} / \mathrm{mL}$; and V: IC50 $7.29 \mu \mathrm{g} / \mathrm{mL}$

probably due to semi polar properties of the hexane solvent [34-35].

Our results revealed that Xestospongia sp., contained more triterpenoid than steroid, and no alkaloid was detected. Extraction and isolation for herbal products may fully be affected by the solvents were used [36], a non polar solvent (e.g. hexane) may lead to locate the secondary metabolites such as steroid, peptide, quinone and polypropionate [37]. Moreover, a semi polar solvent may contain saponine, alkaloid salt, amino acid [37] and polyhydroxysteroide [38].

In the present study, we obtained an $\mathrm{IC}_{50}$ for the extraction step of the Xestospongia is $8.21 \times 10^{-13} \mu \mathrm{g} / \mathrm{mL}$, these concentrate inhibition are lesser than the strain for control, W2: $3.11 \mu \mathrm{g} / \mathrm{mL}$, and a strain on D6: $0.013 \mu \mathrm{g} / \mathrm{mL}$. It's generally admitted that low value of $\mathrm{IC}_{50}$ means that the concentrate has highly potential to inhibit $P$. falciparum [39].

In the fractionation step, we obtained five fractions: I:0.25 g, II:1.46 g, III:1.19 g, IV:1.40 g and fraction $\mathrm{V}: 0.73 \mathrm{~g}$. The inhibition assay against to the parasite of $P$. falciparum, we reported that the fraction IV has highly inhibit $P$. falciparum with a concentration $100 \mu \mathrm{g} / \mathrm{mL}$ $(90.6 \%)$, while fraction I seems to have less inhibited
$(44.62 \%)$. Others fractions were unfairly impeded Plasmodium.

Analysis of quantitative measurement $\left(\mathrm{IC}_{50}\right)$, of these three fractions (i.e II, IV, and V) fairly displayed high inhibition against Plasmodium. The half maximal inhibitory concentration $\left(\mathrm{IC}_{50}\right)$ is commonly used as a measure of antagonist compound in inhibiting biological function [40].

The confrontation of percentage inhibition versus log concentration value of each fraction (Fig. 1) demonstrates a linear curve with the range value between 0.56 and 1.34, manifested a correlation level to about $>90$. Regarding the data obtained in inhibition assay, we clearly reported that fraction IV exhibits more slightly with $\mathrm{IC}_{50}(7.13 \mu \mathrm{g} / \mathrm{mL})$. The smallest value of $I_{50}$ indicates the effectiveness to inhibit a given parasite of Plasmodium [40].

A slight value $\mathrm{IC}_{50}$ designates also that a fraction has highly potential to be antimalarial agent. The obtained value of $\mathrm{IC}_{50}$ in the present work was lower than the common standard used worldwide, stipulating the value $<25 \mu \mathrm{g} / \mathrm{mL}$ [41].

An advanced examination through phytochemistry assay using hexane solvent revealed that fraction IV 


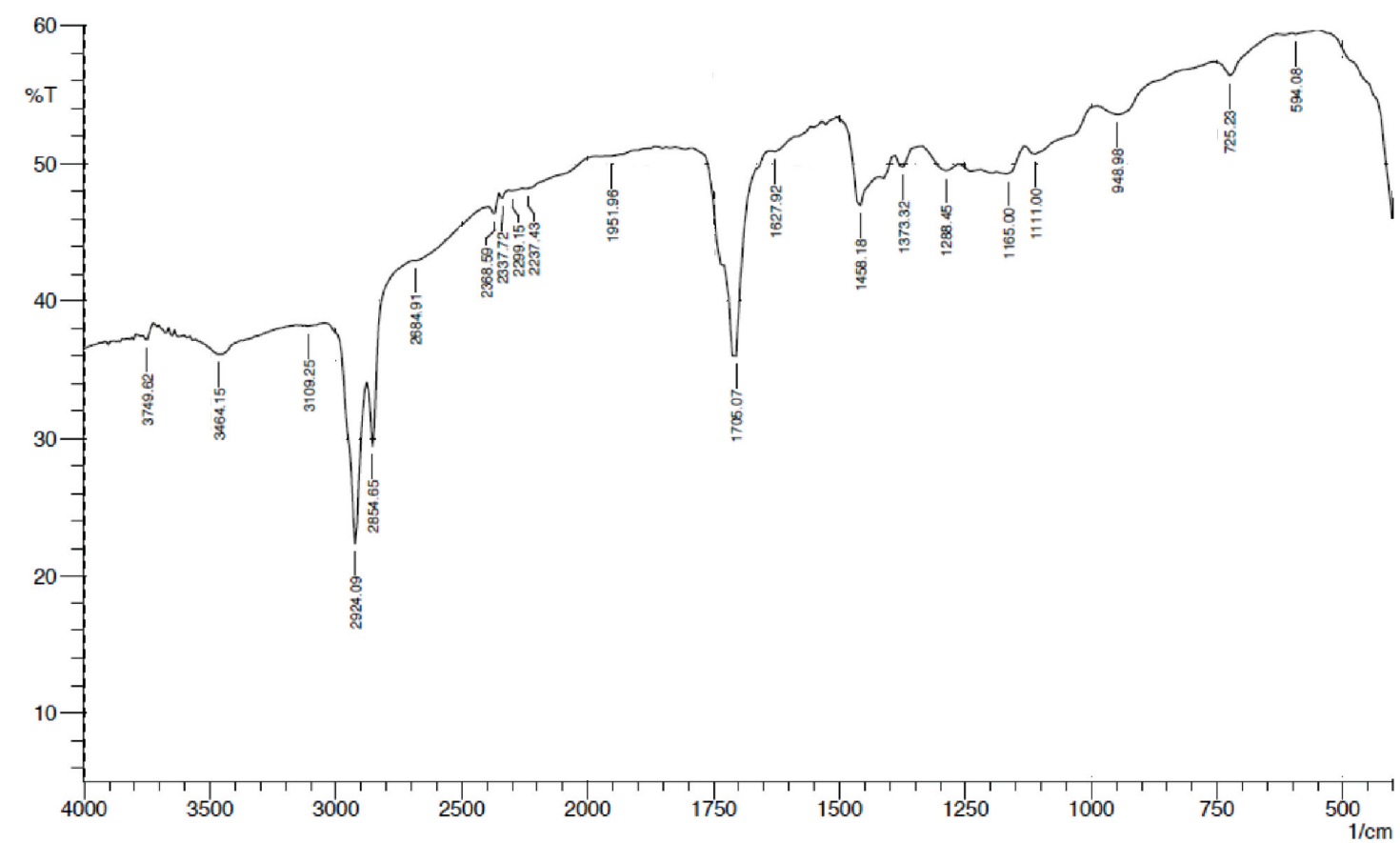

Fig 2. FTIR spectra of the fraction IV using hexane solvent, displayed evidence of the various type of vibrations

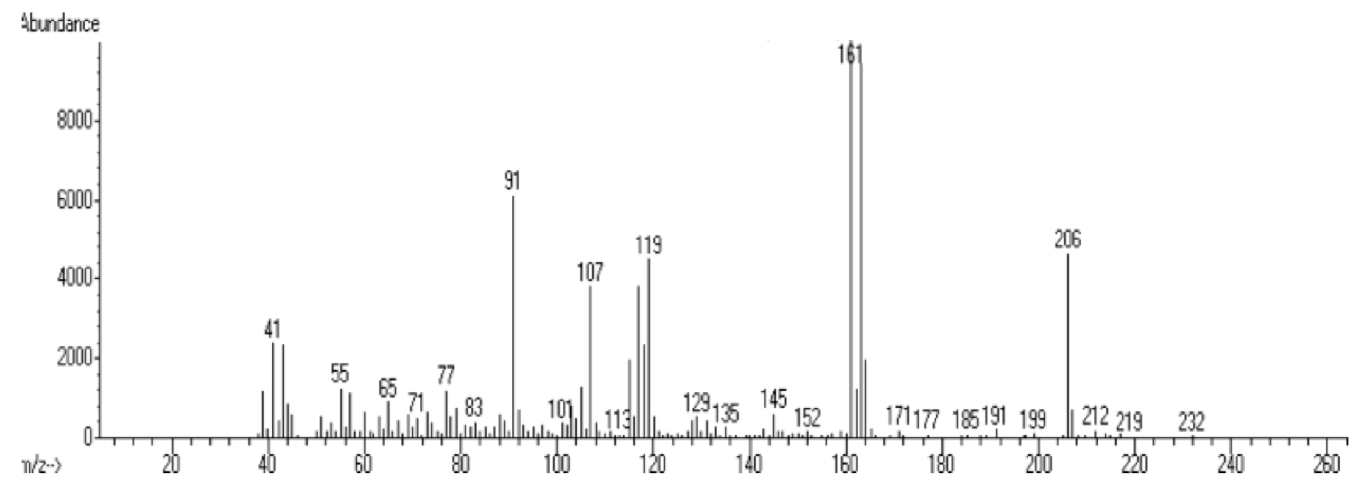

Fig 3. The fragmentation pattern of the GC-MS $\mathrm{m} / \mathrm{z}$ have obtained from isolation record

manifests more profusion of triterpenoid than flavonoid, while steroid was detected negatively.

The Fourier Transform Infrared Spectroscopy (FTIR) of fraction IV (Fig. 2) revealed four typical substituents as follow, first, wavelength ranging between 2854 and $2924 \mathrm{~cm}^{-1}$, related to the type of vibration as carboxylic acids: O-H, frequencies $3400-2400 \mathrm{~cm}^{-1}$ (see Pavia et al. 2001 for designation). Second, wavelength $1705 \mathrm{~cm}^{-1}$, related to carboxylic acids: $\mathrm{C}=\mathrm{O}$, frequencies $1725-1700 \mathrm{~cm}^{-1}$. Third, wavelength $3109 \mathrm{~cm}^{-1}$, related to aliphatic double bond or aromatic stretch: $\mathrm{C}-\mathrm{H}$, frequencies $3100-3000 \mathrm{~cm}^{-1}$. Fourth, wavelength ranging between $1627-1458 \mathrm{~cm}^{-1}$, related to aromatic ring: $C=C$, frequencies $1600-1450 \mathrm{~cm}^{-1}$.

The ${ }^{1} \mathrm{H}-\mathrm{NMR}$ spectra of fraction IV (not presented on the figure), showed three substituents metals at the distinct region are $\delta 0.8 \mathrm{ppm}$; one pair of geminal proton $\delta 1.6 \& 2.3 \mathrm{ppm}$; and one substituent of methylene at $\delta 4.1 \mathrm{ppm}$.

We also recorded three methylenes substituents $\left(\mathrm{CH}_{3}\right)$ performed by the ${ }^{13} \mathrm{C}$-NMR spectra, these three recognized alkanes were found at the difference peak regions that are $\delta 11.6 ; 14.31$ and $14.37 \mathrm{ppm}$. We documented also the presence of a substituent alcohol at $\delta 60.6 \mathrm{ppm}$, a substituent carbonyl $\delta 171.4 \mathrm{ppm}$, and the peaks of methylene at $\delta 20-34 \mathrm{ppm}$ [42].

The analysis of Gas Chromatography-Mass Spectrometry (GC-MS) from fraction IV, represents 25 fragmentation patterns $\mathrm{m} / \mathrm{z}$ as $41,55,65,71,77,83$, $91,101,107,113,119,129,135,145,152,161,171$, 177, 185, 191, 199, 206, 212, 219, and 232 (Fig. 3). A comprehensive analysis based on trio spectras dissections, revealed that these identified substituents are the 2-(4-isobutylphenyl) propanoic acid (Fig. 4). 
<smiles>CC(C)Cc1ccc(C(C)C(=O)O)cc1</smiles>

Fig 4. An identified plausible structure, isolated from Papuan marine sponge Xestospongia sp., 2-(4-isobutylphenyl) propanoic acid

The plausible structure forming a typical fragment (Fig. 4) was a part from terpenoid, identified with the molecular weight of 206. The base structure of those fragments is ibuprofen with a similarity index reaching to about $99 \%$ (time retention 9.22). Those molecular mass can be traced in the fragmentation spectrum of GC-MS [31-33,43].

\section{CONCLUSION}

The Papuan marine sponge of Xestospongia sp., originate from Yapen Island, diagnosed to have an interesting chemicals components in response to the acute human disease such as malarial. The Yapen Island's sponge also contained of plenty of secondary metabolites including flavonoids and triterpenoids. By using the hexane solvent, we obtained unexpected results, stipulating that fraction IV can inhibit Plasmodium with a lower value of $\mathrm{IC}_{50}$. Another important result, we have identified a plausible structure, it proved that the molecule is partly derived from terpenoid properties. Further investigation of the various taxon of the sponge in the area, with a large range collection could be a promising effort to discover much more of the newly compounds for antimalarial.

\section{ACKNOWLEDGEMENT}

This study was funded by the grant of Hibah Bersaing UNIPA (1082/42/KU/2011). We are extremely grateful to $\mathrm{H}$. Werimon, T. Pihahei, E. Rumayomi and $P$. Surbakti for their supports during the field collection, their efforts are greatly appreciated. The authors also thank all staff of Pharmacognosy and Phytochemistry Laboratory UNAIR Surabaya for in vitro malarial examination, and the colleagues of Eijkman Institute for Molecular Biology Jakarta, for their carefully and excellent results of extractions. Without their helps we could not have carried out this study.

\section{REFERENCES}

1. Hay, S.I., Guerra, C.A., Tatem, A.J., Atkinson, P.M., and Snow, R.W., 2005, Nat. Rev. Microbiol., 3, 1, 81-90.
2. Kager, P.A., 2002, Trop. Med. Int. Health, 7, 12, 1042-1046.

3. Bagavan, A., Rahuman, A.A., Kaushik, N.K., and Sahal, D., 2011, Parasitol. Res., 108, 15-22.

4. White, N.J., 1992, Br. J. Clin. Pharmacol., 34, 1, $1-10$.

5. WHO, 2011, http://www.who.int/malaria.20WHO. htm, accessed 10 October 2011.

6. Hay, S.I., Rogers, D.J., Toomer, J.F., and Snow, R.W., 2000, Trans. R. Soc. Trop. Med. Hyg., 94, 2, 113-127.

7. Snow, R.W., Guerra, C.A., Noor, A.M., Myint, H.Y., and Hay, S.I., 2005, Nature, 434, 214-217.

8. Nayyar, G.M., Breman, J.G, Newton P.N., and Herrington, J., 2012, Lancet Infect. Dis., 12, 6, 488-496.

9. Elyazar, I.R.F., Gething, P.W., Patil A.P., Rogayah, H., Kusriastuti, R., Wismarini, D.M., Tarmizi, S.N., Baird, J.K., and Hay, S.I., 2011, PLoS ONE, 6, 6, e21315.

10. Nagesha, H.S., Din-Syafruddin, Casey, G.J., Susanti, A.I., Fryauff, D.J., Reeder, J.C., and Cowman, A.F., 2001, Trans. R. Soc. Trop. Med. Hyg., 95, 1, 43-49.

11. Suwanarusk, R., Russell, B., Chavchich, M., Chalfein, F., Kenangalem, E., Kosaisavee, V., Prasetyorini, B., Piera, K.A., Barends, M., Brockman, A., Lek-Uthai, U., Anstey, N.M., Tjitra, E., Nosten, F., Cheng, Q., and Price, R.N., 2007, PLoS ONE, 2, 10, e1089.

12. Baird, J.K, 2004, Antimicrob. Agents Chemother., 48, 11, 4075-4083.

13. Klein, E.Y., Smith, D.L., Ramanan, L.R., and Simon, L., 2012, Proc. R. Soc. B, 279, 1743, 3834-3842.

14. Goldberg, D.E., Siliciano, R.F., and Jacobs, W.R.Jr., 2012, Cell, 148, 6, 1271-1283.

15. Plowe, C.V., 2005, Curr. Top. Microbiol. Immunol., 295, 55-79.

16. Martin, R.E., Marchetti, R.V., Cowan, A.I., Howitt, S.M., Bröer, S., and Kirk, K., 2009, Science, 325, 5948, 1680-1682.

17. McGready, R., Cho, T., Keo, N.K., Thwai, K.L., Villegas, L., Looareesuwan, S., White, N.J., and Nosten, F., 2001, Clin. Infect. Dis., 33, 12, 2009-2016.

18. Tang, C., Godfrey, T., Stawell, R., and Nikpour, M., 2012, Intern. Med. J., 42, 9, 968-978.

19. Hyde, J.E, 2005, Trends Parasitol., 21, 11, 494-498.

20. Schlitzer, M., 2007, ChemMedChem, 2, 944-986.

21. Ross and Flaningan, 2006, http://www.healthatoz.com, accessed 1 January 2010. 
22. Summers, R.L., Nash, M.N., and Martin, R.E, 2012, Cell. Mol. Life Sci., 69, 12, 1967-1995.

23. Inbaneson, S.J., and Ravikumar, S, 2012, Parasitol. Res., 110, 6, 2255-2262.

24. Davis, R.A., Buchanan, M.S., Duffy, S., Avery, V.M., Charman, S.A., Charman, W.N., White, K.L., Shackleford, D.M., Edstein, M.D., Andrews, K.T., Camp, D., and Quinn, R.J., 2012, J. Med. Chem., $55,12,5851-5858$.

25. McKenna, S.A., Allen, G.R, Suryadi, S., and Rapid Assessment Program 2002, A marine rapid assessment of the Raja Ampat Islands, Papua Province, Indonesia, Washington DC: Conservation International, Center for Applied Biodiversity Science, Dept. of Conservation Biology.

26. McCarthy, P.J., and Pomponi, S.A., 2004, Mar. Biomed. Res., 1-2.

27. Allen, G.R., 2008, Aquat. Conserv., 18, 5, 541-556.

28. Treml, E.A., and Halpin, P.N., 2012, Conserv. Lett., $5,6,441-449$.

29. Swantara, I.M.D., Supriyono, A., and Trinoviani, M., 2007, J. Kimia, 1, 1, 67-79.

30. Harborne, J.B., 1987, Metode Fitokimia, $2^{\text {nd }}$ ed., ITB Bandung, pp.354.

31. Mills, N., 2006, J. Am. Chem. Soc., 128, 41, 13649-13650.

32. Buckingham, J., 1993, Dictionary of Natural Products, Vol. 1, Chapman \& Hall/CRC, London, p. 8584.
33. Jin, Z., 2008, J. Med. Chem., 51, 5, 1501.

34. Morris, S., Bersuder, P., Allchin, C.R., Zegers, B., Boon, J.P., Leonards, P.E., and de Boer, J., 2006, TrAC, Trends Anal. Chem., 25, 4, 343-349.

35. Bintang M., 2010, Biokimia Teknik Penelitian, Erlangga, Jakarta, Ed. xvi, p.256.

36. Ebada, S., Edrada, R.A., Lin, W., and Proksch, P., 2008, Nat. Protoc., 3, 12, 1820-1831.

37. Rivera, A.P., and Uy, M.M., 2012, J. Chem., 9, 1, 354-358.

38. Chaudary, A., Singla, S.K., and Tandon, C., 2010, Indian J. Pharmacol. Sci., 72, 3, 340-345.

39. Wet, D.H., 2005, An Ethnobotanical and Chemataxonomix Study of South African Menispermaceae, Thesis, University of Johannesburg.

40. Baniecki, M.L., Wirth, D.F., and Clardy, J., 2007, Antimicrob. Agents Chemother., 51, 2, 716-723.

41. Ringwald, P., Bickii, J., and Basco, L.K., 1999, Am. J. Trop. Med. Hyg., 61, 2, 187-192.

42. Pavia, D.L., Lampman, G.M., Kriz G.S., 2001, Introduction to Spectroscopy, $3^{\text {rd }}$ ed., Brooks/Cole Thomson Learning, p. 390.

43. Blunt, J.W., and Munro, M.H.G., 2007, Dictionary of Marine Natural Products with CD-ROM, Boca Raton: Chapman and Hall/CRC. 